\title{
PENGARUH LOYALITAS KARYAWAN (ORGANIZATIONAL CITIZENSHIP BEHAVIOR) DAN PENERAPAN TEORI DUA FAKTOR (TWO FACTOR THEORIES) TERHADAP KINERJA PERUSAHAAN
}

\author{
Eva Fauziana, Sena Maulana, Oni Junianto, Sarfilianty Anggiani \\ Institut Bisnis Muhammadiyah Bekasi, Indonesia \\ Universitas Trisakti, Jakarta, Indonesia \\ Email: evafauziana@ibm.ac.id, sena.tni24@gmail.com, onssespimti29@gmail.com, \\ sarfilinty@trisakti.ac.id
}

\begin{abstract}
Abstrak
Organizational Citizenship Behavior (OCB) atau loyalitas dan kelekatan karyawan terhadap organisasi, dewasa ini menjadi salah satu program divisi SDM di banyak perusahaan untuk terus dikembangkan dan diimplementasikan dalam kegiatan operasional perusahaan. Penelitian ini menganalisis sejauh mana loyalitas dan kelekatan karyawan terhadap organisasi berpengaruh terhadap kinerja organisasi atau perusahaan. Penelitian ini mengambil data random responden dari berbagai industri, posisi dalam organisasi, serta spesifikasi peran dan tanggung jawab tiap responden dalam organisasi. Loyalitas karyawan yang dimaksud adalah tentang seberapa kuat karyawan bangga dan percaya terhadap perusahaannya, serta seberapa paham mereka memahami visi misi serta rencana strategis yang diemban perusahaan. Ada pun Teori Dua Faktor yang terangkum dalam penelitian ini adalah mengenai prosedur dan tata kelola yang ditetapkan perusahaan, hubungan antara atasan-bawahan dan rekan kerja, lingkungan fisik tempat kerja, program kesejahteraan karyawan yang ditawarkan perusahaan, serta seberapa jauh pekerjaan yang karyawan emban mampu memotivasi mereka. Hasil dari penelitian ini mengungkapkan bahwa Teori Dua Faktor jauh lebih berpengaruh dalam meningkatkan kinerja perusahaan.
\end{abstract}

Kata Kunci: loyalitas karyawan; teori dua faktor; manajemen kinerja

Abstract
Organizational Citizenship Behavior becomes one of Human Resources
Division programs to be developed and implemented in operational level in
many companies. This research analysis how organizational citizenship
behavior gives impact to company performance. This study takes random
sampling from many industries, job position and job specification and job
roles and responsibilities in each respondent. Organizational Citizenship
Behavior in this case, focused on how employees trust and proud to their
organization, and how they understand company's vision, mission and
strategic plan from year to year. While Two Factors Theories in this
research, focused on the dimensions of procedures implemented in
How to cite:
Fauziana. E. et.al (2021) Pengaruh Loyalitas Karyawan (Organizational Citizenship Behavior) dan
E-IsSN:
Published by: $\quad$ Jurnal Ilmiah Indonesia Fator (Two Factor Theories) Terhadap Kinerja Perusahaan, 6(2), Syntax Literate:


Pengaruh Loyalitas Karyawan (Organizational Citizenship Behavior) dan Penerapan Teori Dua Faktor (Two Factor Theories) Terhadap Kinerja Perusahaan

operational activities, relationship between superiors and subordinates and among team members, physical working condition, compensation and benefit program. While other dimensions are how the job itself could give moderate challenge, pride, and give them higher career challenges.

Keywords: organizational citizenship behavior; two factor theories; performance management

Received: 2021-10-20; Accepted: 2021-11-05; Published: 2021-11-20

\section{Pendahuluan}

Di era turbulensi yang sangat dinamis ini, ditambah lagi dengan pandemi yang mewabah di seluruh dunia, membuat tiap organisasi wajib melakukan perubahan di tiap lini organisasi mereka. Perubahan tersebut minimal mampu mencakup empat area utama yang signifikan dalam pencapaian kinerja perusahaan.

Manajemen kinerja secara perlahan bergeser, dari evaluasi kinerja berdasarkan tugas dan kedisiplinan karyawan, kini berkembang menjadi bagaimana sudut pandang karyawan terhadap organisasi, akan berpengaruh terhadap kinerja dirinya dan tentu saja berpengaruh terhadap kinerja organisasi secara keseluruhan.

Organizational Citizenship Behavior (OCB) atau dalam bahasa ringkasnya dapat disebut sebagai keletakan dan loyalitas karyawan terhadap organisasi, merujuk pada perilaku tertentu yang ditunjukkan oleh karyawan, tapi tanpa menuruti prosedur formal dalam internal organisasi, namun menunjukkan keinginan karyawan untuk sepakat mencapai kinerja terbaik demi mencapai tujuan organisasi (Wang, et al, 2005).

OCB sendiri dibagi menjadi dua jenis, yaitu perilaku individu (karyawan) terhadap organisasi (Williams \& Anderson, 1991) dan perilaku antar individu dalam organisasi (Cohen, 2006).

Locke dan Latham (1990) mendefinisikan kepuasan dan motivasi karyawan dalam pekerjaan dalam dua variabel mendasar, yaitu (1) faktor hygiene dan (2) faktor motivasi. Faktor hygiene ini meliputi ketersediaan aturan dan prosedur kerja yang jelas, lingkungan fisik yang aman dan nyaman dalam pekerjaan, serta relasi dan komunikasi yang baik dalam tim internal. Selain itu, faktor benefit yang diterima karyawan juga turut menentukan tingkat kepuasan karyawan.

Adapun faktor motivasi yang dapat mempengaruhi motivasi dan kinerja karyawan antara lain adanya pekerjaan yang menantang karyawan untuk selalu berprestasi, adanya jenjang karir yang jelas yang dapat membuat karyawan bangga terhadap pekerjaan dan profesinya sendiri (Jalagat Jr \& Aquino Jr, 2021).

Teori dua Faktor ini sebetulnya pengembangan dari teori dasar kebutuhan menurut Maslow (1943), menyebutkan hirarki kebutuhan manusia dari yang paling bawah adalah (1) kebutuhan sandang, pangan, papan dan perasaan dicintai, lalu meningkat kepada (2) kebutuhan akan rasa aman dalam pekerjaan, (3) kebutuhan untuk dikenali di lingkungan sosial, (4) kebutuhan akan pekerjaan atau status sosial yang bisa 
Eva Fauziana, Sena Maulana, Oni Junianto, Sarfilianty Anggiani

dibanggakan, dan yang terakhir (5) kebutuhan akan aktualisasi diri di tempat pekerjaan dan masyarakat (David \& Andrezei, 1997).

Dalam perkembangannya, OCB membantu perusahaan mengembangkan lingkungan kerja yang lebih kondusif dari sisi psikologis dalam mendukung keberhasilan kinerja. OCB juga mengembangkan sosial kapital perusahaan dan meningkatkan efisiensi serta efektivas organisasi secara keseluruhan.

\section{Metode Penelitian}

Metode penelitian yang digunakan dalam penelitian ini adalah metode kuantitatif dengan menggunakan metode Analisis Structural Equation Model (SEM) dengan penyebaran kuesioner berdasarkan skala Likert. Responden berjumlah 135 orang, dengan uji keabsahan data mencakup $10 \%$ (sepuluh persen) dari total responden.

\section{Hasil dan Pembahasan}

Adapun hasil dari penelitian kami, dijabarkan dalam tabel sebagai berikut:

\section{Data Responden}

\section{Tabel 1}

Jenis Kelamin

\begin{tabular}{ccc}
\hline Jenis Kelamin & f & \% \\
\hline Pria & 60 & 44.4 \\
\hline Wanita & 75 & 55.6 \\
\hline Total & 135 & 100 \\
\hline
\end{tabular}

Tabel diatas menggambarkan data responden berdasarkan jenis kelamin. Dari 135 orang yang diteliti, peling banyak responden berjenis kelamin wanita yaitu 75 orang $(55,6 \%)$.

Tabel 2

Tabel Usia

\begin{tabular}{lll}
\hline Usia & f & $\mathbf{\%}$ \\
\hline 19-25 tahun & 20 & 14.8 \\
\hline $26-29$ tahun & 18 & 13.3 \\
\hline $30-35$ tahun & 21 & 15.6 \\
\hline 36-39 tahun & 13 & 9.6 \\
\hline 40-45 tahun & 30 & 22.2 \\
\hline 46-49 tahun & 15 & 11.1 \\
\hline 50-59 tahun & 16 & 11.9 \\
\hline 60-69 tahun & 1 & 0.7 \\
\hline di atas 70 tahun & 1 & 0.7 \\
\hline Total & 135 & 100 \\
\hline
\end{tabular}

Tabel diatas menggambarkan data responden berdasarkan usia. Dari 135 orang yang diteliti, paling banyak responden berusia antara 40 sampai 45 tahun yaitu 30 orang $(22,2 \%)$. 
Pengaruh Loyalitas Karyawan (Organizational Citizenship Behavior) dan Penerapan Teori Dua Faktor (Two Factor Theories) Terhadap Kinerja Perusahaan

Tabel 3

Instansi Tempat Kerja

\begin{tabular}{lll}
\hline Instansi Tempat Kerja & f & \% \\
\hline Anggota Aktif TNI & 1 & 0.7 \\
\hline BUMN / BUMD & 24 & 17.8 \\
\hline Institusi Pendidikan & 28 & 20.7 \\
\hline Karyawan Pindad Engineering Indonesia & 27 & 20 \\
\hline Perusahaan Swasta Multinasional (PMA) & 10 & 7.4 \\
\hline Perusahaan Swasta Nasional & 33 & 24.4 \\
\hline PNS non TNI / non Polri & 5 & 3.7 \\
\hline Wirausaha & 6 & 4.4 \\
\hline Yayasan Nirlaba / NGO & 1 & 0.7 \\
\hline Total & 135 & 100 \\
\hline
\end{tabular}

Tabel diatas menggambarkan data responden berdasarkan instansi tempat kerja. Dari 135 orang yang diteliti, paling banyak responden di instansi Perusahaan Swasta Nasional yaitu 33 orang $(24,4 \%)$.

Tabel 4

Jabatan

\begin{tabular}{lll}
\hline Jabatan & f & $\%$ \\
\hline Pemilik Usaha / Owner / Founder & 2 & 1.5 \\
\hline Penyelia / Supervisor & 21 & 15.6 \\
\hline Pimpinan Madya / Middle Manager & 27 & 20 \\
\hline Pimpinan Muda / Junior Manager / Kepala Lembaga & 19 & 14.1 \\
\hline Pimpinan Puncak / Direksi & 5 & 3.7 \\
\hline Staf & 61 & 45.2 \\
\hline Total & 135 & 100 \\
\hline
\end{tabular}

Tabel diatas menggambarkan data responden berdasarkan jabatan. Dari 135 orang yang diteliti, paling banyak responden dengan jabatan staf yaitu 61 orang $(45,2 \%)$.

Tabel 5

Domisili

\begin{tabular}{lll}
\hline Domisili & f & \% \\
\hline Di Luar Pulau Jawa & 7 & 5.2 \\
\hline Jabodetabek & 59 & 43.7 \\
\hline Jawa Barat di luar Jabodetabek & 51 & 37.8 \\
\hline Pulau Jawa & 18 & 13.3 \\
\hline Total & 135 & 100 \\
\hline
\end{tabular}

Tabel diatas menggambarkan data responden berdasarkan Domisili. Dari 135 orang yang diteliti, paling banyak responden berdomisili di Jabodetabek yaitu 59 orang $(43,7 \%)$. 
Eva Fauziana, Sena Maulana, Oni Junianto, Sarfilianty Anggiani

Tabel 6

Status

\begin{tabular}{lll}
\hline Status & f & \% \\
\hline Bercerai / Pisah Mati & 5 & 3.7 \\
\hline Menikah & 98 & 72.6 \\
\hline Single & 32 & 23.7 \\
\hline Total & 135 & 100 \\
\hline
\end{tabular}

Tabel diatas menggambarkan data responden berdasarkan Status. Dari 135 orang yang diteliti, paling banyak responden dengan status menikah yaitu 98 orang $(72,6 \%)$.

Tabel 7

Pendidikan

\begin{tabular}{lll}
\hline Pendidikan & f & \% \\
\hline S1 & 71 & 52.6 \\
\hline S2 & 36 & 26.7 \\
\hline S3 & 4 & 3 \\
\hline SMA & 24 & 17.8 \\
\hline Total & 135 & 100
\end{tabular}

Tabel diatas menggambarkan data responden berdasarkan pendidikan. Dari 135 orang yang diteliti, paling banyak responden dengan Pendidikan S1 yaitu 71 orang $(52,6 \%)$.

Tabel 8

Jarak dari Rumah ke Kantor

\begin{tabular}{lll}
\hline Jarak dari Rumah ke Kantor & f & \% \\
\hline Berbeda kota tapi masih satu provinsi & 11 & 8.1 \\
\hline Berbeda provinsi & 6 & 4.4 \\
\hline Berbeda wilayah negara & 2 & 1.5 \\
\hline Dekat, kurang dari $50 \mathrm{~km}$ & 116 & 85.9 \\
\hline Total & 135 & 100 \\
\hline
\end{tabular}

Tabel diatas menggambarkan data responden berdasarkan Jarak dari Rumah ke Kantor. Dari 135 orang yang diteliti, paling banyak responden menjawab "Dekat, kurang dari 50 km" yaitu 116 orang $(85,9 \%)$.

Tabel 9

Fungsi Utama Pekerjaan

\begin{tabular}{lll}
\hline Fungsi Utama Pekerjaan & f & \% \\
\hline Administrasi \& Pelaksana & 36 & 26.7 \\
\hline Engineering / Teknisi & 14 & 10.4 \\
\hline Manajemen & 45 & 33.3 \\
\hline Pemasaran & 11 & 8.1 \\
\hline Pengajar (Guru/Dosen/Tutorial) & 20 & 14.8 \\
\hline Riset \& Pengembangan & 9 & 6.7 \\
\hline Total & 135 & 100 \\
\hline
\end{tabular}


Tabel diatas menggambarkan data responden berdasarkan fungsi utama pekerjaan. Dari 135 orang yang diteliti, paling banyak responden menjawab "Manajemen" yaitu 45 orang $(33,3 \%)$.

\section{Analisis Structural Equation Model (SEM)}

Pada penelitian ini terdapat 3variabel laten dan 8 variabel manifest. Pengujian hasil struktur equation modeling (SEM) dengan pendekatan partial least square (PLS) dilakukan dengan melihat hasil model pengukuran (outer model) dan hasil model structural (inner model) dari model yang dilteliti.

\section{Pengujian Model Pengukuran (Outer Model)}

Covergent Validity berhubungan dengan prisnsip bahwa variabel manifest dari suatu konstruk seharusnya berkorelasi tinggi. Covergent Validity dengan software PLS dapat dilihat dari loading factor untuk setiap indicator konstruk, adapun untuk menilai Covergent Validity nilai loading factor harus lebih dar 0,6 , serta average extracted (AVE) harus lebih besar dari 0,5, diperoleh hasil sebagai berikut:

\section{Loading Factor}

Tabel 10

Loading Factor

\begin{tabular}{lll}
\hline Variabel & Variabel Manifest & Loading Factor \\
\hline \multirow{2}{*}{ Two Factor } & HF & 0.934 \\
\cline { 2 - 3 } & MF & 0.914 \\
\hline \multirow{2}{*}{ OCB } & KTP & 0.903 \\
\cline { 2 - 3 } & KVM & 0.626 \\
\cline { 2 - 3 } Kinerja & Percaya & 0.856 \\
Perusahaan & CF & 0.837 \\
\cline { 2 - 3 } & FP & 0.888 \\
\hline
\end{tabular}

Tabel di atas memberikan informasi mengenai nilai loading factor untuk setiap variabel manifest, nilai loading factor dari semua indicator terhadap variabel laten menunjukan $>0,6$, sehingga semua indicator dinyatakan valid dan mampu mengukur variabel secara tepat.

Average Variance Extracted (AVE)

Tabel 11

Average Variance Extracted

\begin{tabular}{llll}
\hline & $\begin{array}{l}\text { Average Variance } \\
\text { (AVE) }\end{array}$ & \\
\hline Kinerja_Perusahaan & 0.732 & \\
\hline OCB & 0.647 & \\
\hline Two Factor & 0.854 & \\
\hline
\end{tabular}


Eva Fauziana, Sena Maulana, Oni Junianto, Sarfilianty Anggiani

Pada tabel di atas, dapat dilihat bahwa keenam variabel laten memiliki nilai AVE yang lebih besar dari nilai yang ditentukan yakni sebesar 0,5. Sehingga semua variabel dinyatakan valid dalam menjelaskan variabel latennya yang menunjukan bahwa penggunaan variabel manifest tersebut memenuhi persyaratan AVE.

Maka dari itu seluruh variabel manifest dinyatakan telah memenuhi persyaratan convergent validity. Convergent validity itu sendiri merupakan validitas yang terbukti jika skor yang diperoleh oleh instrument yang mengkur konsep atau mengukur konsep dengan metode yang berbeda memiliki korelasi yang tinggi.

\section{Discriminant Validity}

Discriminant Validity dapat dilihat dari pengkran cros loading factor dengan kosntruk dan perbandingan AVE dengan korelasi variabel laten. Jika korelasi kosntruk dengan pokok pengukuran (setiap indicator) lebih besar daripada ukuran kosntruk lainnya maka dikatakan variabel tersebut memiliki validitas diskriminan yang tinggi. Nilai cross loading disajikan sebagai berikut:

Tabel 12

Hasil Uji Cross Loading Faktor

\begin{tabular}{llll}
\hline & Two Factor & OCB & Kinerja_Perusahaan \\
\hline HF & 0.934 & 0.707 & 0.799 \\
\hline MF & 0.914 & 0.606 & 0.704 \\
\hline KTP & 0.637 & 0.903 & 0.733 \\
\hline KVM & 0.518 & 0.626 & 0.503 \\
\hline Percaya & 0.561 & 0.856 & 0.605 \\
\hline CF & 0.671 & 0.719 & 0.837 \\
\hline FP & 0.705 & 0.656 & 0.888 \\
\hline IP & 0.719 & 0.607 & 0.840 \\
\hline
\end{tabular}

Berdaarkan tabel hasil software PLS di atas, terlihat nilai cross loading factor korelsi setiap kosntruk laten untuk indicator yang berseuaian lebih tinggi daripada kostruk lainnya, sehingga dapat disimpulkan bahwa indicator-indikator yang digunakan untuk mengukur variabel laten telah memenuhi syarat.

\section{Uji Reliabilitas}

Uji reliabiltas dalam Partial Least Square (PLS) dapat menggunakan dua metode yakni Composite Reliability (CR) dan Cronbach's Alpha, yang disajikan sebagai berikut: 
Tabel 13

Hasil Uji Composite Reliability (CR) dan Cronbach's Alpha

\begin{tabular}{lll}
\hline & $\begin{array}{l}\text { Cronbach's } \\
\text { Alpha }\end{array}$ & $\begin{array}{l}\text { Composite } \\
\text { Reliability }\end{array}$ \\
\hline Kinerja_Perusahaan & 0.816 & 0.891 \\
\hline OCB & 0.715 & 0.843 \\
\hline Two Factor & 0.829 & 0.921 \\
\hline
\end{tabular}

Dari hasil pengujian diatas dapat diketahui bahwa nilai Composite Reliability (CR) lebih besar dari 0,7 dan nilai Cronbachs Alpha lebih besar dari 0,6, sehingga dapat disimpulkan bahwa data reliabel yang menunjukkan bahwa semua indikator memiliki kekonsistenan dalam mengukur masing-masing variabel.

\section{Pengujian Model Struktural (Inner Model)}

Pengukuran model structural ini adalah menguji pengaruh satu variabel laten dengan variabel laten lainnya. Pengujian dilakukan dengan melihat nilai path yang untuk melihatnya apakah pengaruh tersebut signifikan atau tidak dilihat dari nilai t dari nilai path (nilai $t$ dapat diperoleh dengan melakukan boothstraping). Berikut adalah gambar dari hasil boothstraping yang dilakukan dalam penelitian ini:

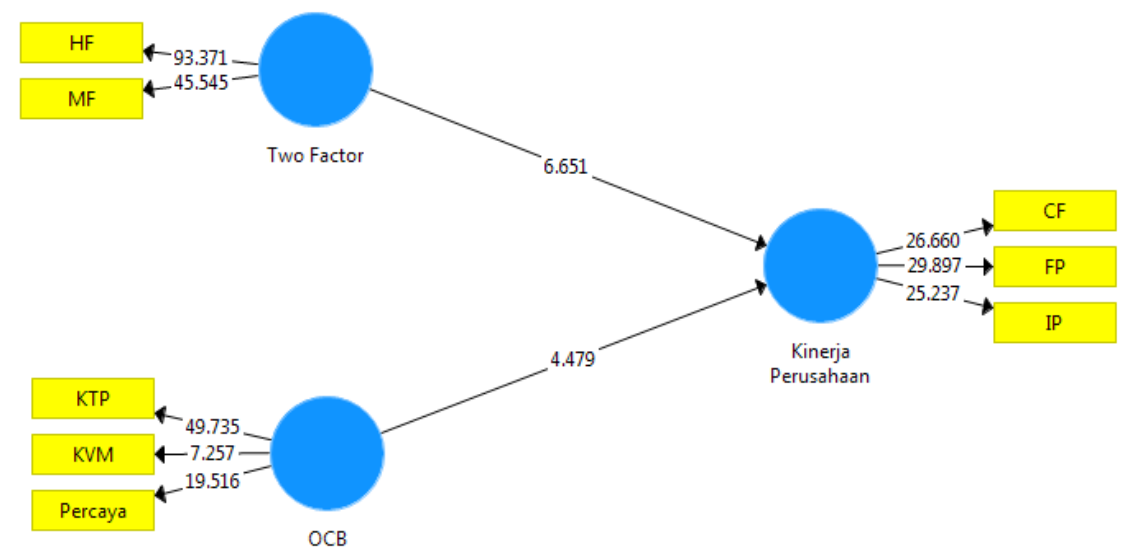

Gambar 1 Boothstraping

\section{Uji R square}

Pengaruh variabel dependen dapat ditampilkan oleh nilai R-square. Berikut perolehan nilai R-square.

Tabel 14

Hasil R Square

\begin{tabular}{ll}
\hline & R Square \\
\hline Kinerja_Perusahaan & 0.740 \\
\hline
\end{tabular}


Melalui nilai koefisien determinasi (R-square) yang terdapat pada Tabel diatas dapat diketahui pada nilai Rsquare variabel kinerja perusahaan sebesar 0,740 , yang menunjukan bahwa kinerja perusahaan dapat dijelaskan sebesar $74,0 \%$ oleh variabel two factor dan OCB. Dilihat dari koefisien jalurnya, kinerja perusahaan lebih dominan dipengaruhi oleh two faktor dengan koefisien jalur sebesar 0,539 dan yang paling kecil pengaruhnya adalah variabel OCB dengan koefisien jalur sebesar 0,389.

\section{Pengujian Hipotesis}

Hipotesis dalam penelitian ini akan diuji dengan menggunakan nilai koefisien path dan $t$ values untuk melihat apakah ada pengaruh signifikan atau tidak. Selain itu, hasil pengujian signifikansi jalur juga memperlihatkan nilaii koefisien parameternya (original sampel). Koefisien parameter memperlihatkan nilai signifikansi dari pengaruh masing-masing variabel penelitian.

Tabel 15

Uji Signifikansi Jalur (Path)

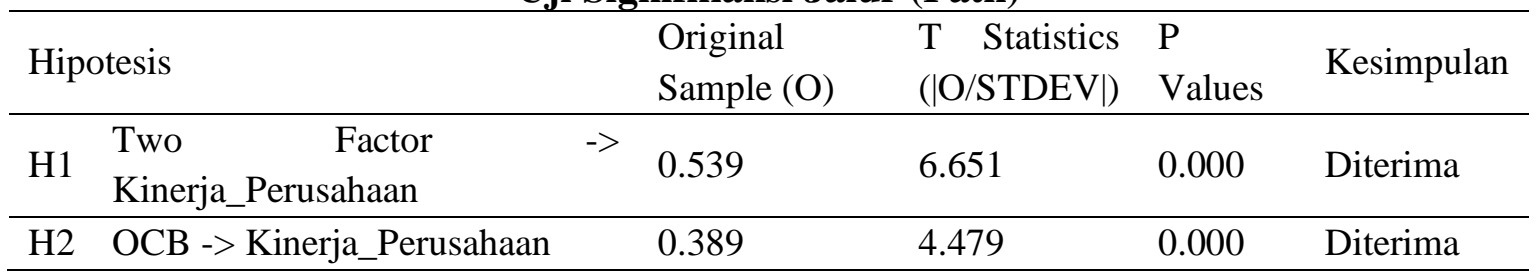

\section{Pengaruh Two Factor Theories Terhadap Kinerja Perusahaan}

Ho: Two Factor tidak berpengaruh signifikan positif terhadap Kinerja Perusahaan

H1: Two Factor berpengaruh signifikan positif terhadap Kinerja Perusahaan

Tolak Ho dan terima $\mathrm{H} 1$ jika nilai $t_{\text {hitung }}>\mathrm{t}_{\text {tabel }}$

Untuk menguji hipotesis di atas, gigunakan nilai t-value untuk melihat pengaruh

Two Factor terhadap kinerja perusahaan dengan nilai t-value 6,651, nilai ini lebih besar dari 1,96 dengan $a=0,05$, sehingga dapat disimpulkan $\mathrm{H} 1$ diterima, artinya terdapat pengaruh signifikan Two Factor terhadap kinerja perusahaan.

Variabel Two Factor terhadap kinerja perusahaan memiliki original sampel sebesar 0,539 dengan arah positif artinya semakin baik Two Factor maka kinerja perusahaan juga akan semakin meningkat sebesar 0,539.

\section{Pengaruh Organization Citizenship Behavior Terhadap Kinerja Perusahaan}

Ho: OCB tidak berpengaruh signifikan positif terhadap Kinerja Perusahaan

H2: OCB berpengaruh signifikan positif terhadap Kinerja Perusahaan

Tolak Ho dan terima $\mathrm{H} 2$ jika nilai $t_{\text {hitung }}>\mathrm{t}_{\text {tabel }}$

Untuk menguji hipotesis di atas, gigunakan nilai t-value untuk melihat pengaruh OCB terhadap kinerja perusahaan dengan nilai t-value 4,479, nilai ini lebih besar dari 1,96 dengan $\mathrm{a}=0,05$, sehingga dapat disimpulkan $\mathrm{H} 2$ diterima, artinya terdapat pengaruh signifikan OCB terhadap kinerja perusahaan. 
Variabel OCB terhadap kinerja perusahaan memiliki original sampel sebesar 0,389 dengan arah positif artinya semakin baik OCB maka kinerja perusahaan juga akan semakin meningkat sebesar 0,389 .

\section{Kesimpulan}

Untuk meningkatkan kinerja organisasi atau perusahaan secara signifikan, penulis menyarankan untuk lebih menekankan pengembangan area sumber daya manusia pada perbaikan pada dimensi sebagai berikut:

1. Memberikan pekerjaan yang terarah dan terstuktur sesuai target organisasi.

2. Memberikan pekerjaan dengan tantangan yang sesuai dengan kemampuan masingmasing karyawan.

3. Memberikan motivasi dengan cara melakukan komunikasi dan pendekatan yang efektif kepada tim terkait secara formal dan informal

4. Memperhatikan lingkungan fisik kantor atau pabrik tempat usaha, sehingga terpenuhi kebersihan keselamatan, keamanan dan kenyamanan karyawan.

5. Secara berkala mengkaji ulang sistem penggajian, sehingga tetap memenuhi kebutuhan dasar karyawan.

Penulis juga hendak menyarankan para pengelola organisasi dan perusahaan untuk secara bekala melakukan sosialisasi dan internalisasi visi misi perusahaan kepada seluruh karyawan, termasuk rencana stratejik serta target apa yang hendak dicapai dalam kurun waktu tertentu, sehingga karyawan memiliki rasa percaya, bangga, dan termotivasi untuk menghasilkan kinerja sesuai target yang telah disepakati.

Untuk penelitian selanjutnya, penulis menyarankan menggunakan jumlah responden yang lebih banyak dan lebih luas, dan responden secara spesifik fokus pada fungsi dan jabatan tertentu, serta menambahkan dimensi kehadiran karyawan dalam penelitian, serta menjabarkan secara umum hasil kinerja atau pencapaian target perusahaan secara data dalam angka statistik, dalam kurun waktu minimal tiga tahun ke belakang. 
Eva Fauziana, Sena Maulana, Oni Junianto, Sarfilianty Anggiani

\section{BIBLIOGRAFI}

Cohen, A. (2006). The relationship between multiple commitments and organizational citizenship behavior in Arab and Jewish culture. Journal of Vocational Behavior, 69(1), 105-118. Google Scholar

David, B., \& Andrezei, H. (1997). Organizational behavior. United Kingdom, Prentice Hall. Google Scholar

Jalagat Jr, R. C., \& Aquino Jr, P. G. (2021). Common Perceived Predictors of Job Satisfaction Among Filipino Workers in Vietnam. Management Research \& Practice, 13(3). Google Scholar

Locke, E. A., \& Latham, G. P. (1990). Work motivation and satisfaction: Light at the end of the tunnel. Psychological Science, 1(4), 240-246. Google Scholar

Maslow, A. (1943). Maslow's hierarchy of needs. Index of DOCS/Teacing \{sp\} Collection/Honolulu. Google Scholar

Williams, L. J., \& Anderson, S. E. (1991). Job satisfaction and organizational commitment as predictors of organizational citizenship and in-role behaviors. Journal of Management, 17(3), 601-617. Google Scholar

\section{Copyright holder:}

Eva Fauziana, Sena Maulana, Oni Junianto, Sarfilianty Anggiani (2021)

First publication right:

Syntax Literate: Jurnal Ilmiah Indonesia

This article is licensed under:

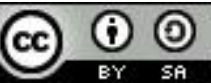

